Article

\title{
Do Oil Price Shocks and Other Factors Create Bigger Impacts on Islamic Banks than Conventional Banks?
}

\author{
Jabir Esmaeil ${ }^{1}$, Husam Rjoub ${ }^{2, *(\mathbb{C})}$ and Wing-Keung Wong $3,4,5$ (i) \\ 1 Department of Banking and Finance, Faculty of Economics and Administrative Sciences, \\ Cyprus International University, Mersin 10, Haspolat 99040, Cyprus; 20162484@student.ciu.edu.tr \\ 2 Department of Accounting and Finance, Faculty of Economics and Administrative Sciences, \\ Cyprus International University, Mersin 10, Haspolat 99040, Cyprus \\ 3 Department of Finance, Fintech Center, and Big Data Research Center, Asia University, Taichung 41354, \\ Taiwan; wong@asia.edu.tw \\ 4 Department of Medical Research, China Medical University Hospital, Taichung 404, Taiwan \\ 5 Department of Economics and Finance, The Hang Seng University of Hong Kong, Xiaoliyuan, Hong Kong \\ * Correspondence: hrjoub@ciu.edu.tr; Tel.: +90-542-878-2128
}

Received: 12 April 2020; Accepted: 5 June 2020; Published: 16 June 2020

\begin{abstract}
The main aim of this study is to empirically examine and compares the impacts of oil price shocks, Arab revolutions, some macroeconomics, and bank-specific variables on bank profitability indicators between Conventional and Islamic banks in Gulf Cooperation Council (GCC) countries. The study employed panel Autoregressive-Distributed Lag (ARDL) techniques to examine the causal relationship both at the short and long-run. Our results reveal that most of the variables employed in our study significantly influence Return on Asset (ROA), Return on Equity (ROE), and Net Interest Margin (NIM)/ Net Profit Margin (NPM) for both Conventional Banks (CBs) and Islamic Banks (IBs) similarly in the long run. Findings from our study imply that both CBs and IBs have some similar features in nature, which could be because of the structure of the policies for IBs is in line with the regulatory framework for the CBs. The main finding from the study is the significance of oil price shock and the Arab springs that are more pronounced in CBs than IBs. Also, it can be seen that a sustainable profit of IBs is higher than CBs due to the adjustment speed of IBs to equilibrium in the presence of shock is found to be higher than CBs. Hence, our study suggests that oil price shock could be utilized for having a prudent macro regulation for the banks in GCC countries. Our findings are useful to Government officers, bankers, investors, and researchers for their decision making by estimating future trends of the profitability for both Conventional and Islamic banks in the GCC countries.
\end{abstract}

Keywords: sustainability; bank profitability; conventional and islamic banks; panel ARDL; GCC countries

JEL Classification: C23; G12; G21

\section{Introduction}

Banking has a strong influence on both industrial prosperity and stability [1]. Banking is an important economic provider. Islamic banking in many countries worldwide is recognized to be commonly used. The history of Islamic banks in 70 countries has extended to over 300 financial institutions. However, there are limited and insufficient empirical evidence for earlier research on Islamic banks' performance in contrast to conventional banks [2]. Rentable lending is an important element in the preservation of banks' survival [3]. The most widely employed productivity metrics 
in the literature are ROA, ROE, NIM and NPM. Numerous experts, officials from Islamic banks and financial institutions have stressed that the global financial crisis does not affect Islamic banks and that its impact on the Islamic banking sector is limited. The GCC countries share the same economic features, including the same historical and cultural developments. Moreover, the GCC provides an interesting setting for the studies and awareness of the potential effects on Islamic and traditional financial performance in GCC countries from the banking, industry and macroeconomic variables, thanks to its distinguishing bank structure.

The GCC which has witnessed the Arab Spring in recent times and can have a significant impact on Muslim and conventional financial performance, is also part of the Arab world. Moreover, it was not empirically or adequately analyzed to determine which of these two banks was the most impacted by the shock to Arab and Spring oil prices. In order to fill the gap in the literature, the motivation behind this paper is to explore the impacts on the sustainability of bank profitability between conventional and Islamic banks of the oil price shocks, the Arab revolutions, some macroeconomics and the bank variables. The reasoning behind this study is also the difference in sustaining bank profitability between Islamic and conventional banks in the GCC region as well as the impact of oil and Arab Spring shocks. Furthermore, there is little empirical research in the Gulf Cooperation Council countries on the determinants of Islamic and traditional financial performance. The bulk of studies was based on evaluating the Gulf Cooperation Council countries' commercial banks, not Islamic banks. In addition, most, if not all, previous studies use not as many variables as they did in our study. Therefore, as far as we know our research is one paper that aims, across the macroeconomic variables of GCC countries, only lead to a growing of both Islamic and traditional banking services in the market, oil prices and the Arab Spring.

The main objective of our paper is to highlight the consequences for the sustainability of bank performance between the Conventional and Islamic financial institutions of the oil prices, the Arab revolutions, and the macroeconomics and banking changes. Comparing the sustainability of profitability determinants and examining their casual relationships with traditional and Islamic banks in the countries of the GCC.

As we know, there is no research explicitly examined in the countries (GCC) and the viability of bank profitably using the comparative study of conventional and Islamic banks with the same factors, particularly oil prices, in our research. This study contains the following contribution to the literature: Secondly, the Analysis would have an effect on the sustained income of Islamic and traditional banks on banks' specific factors and the overall macroeconomic and financial turmoil, the Revolutions of the Arab Spring, and the oil price crisis. In addition, our study fills the gap in the literature by using ROA and ROE and NIM, using both bank specific and macroeconomic variables to analyze the sustainable development of profits factors for Islamic banks and using both the ARDL Tablet Technologies and the Error Correction Model. Our findings show that, for both conventional banks (CBs) and Islamic banks (IBs), several of the variables in our analysis do have a significant long-lasting effect on return on investment. The findings of our study show that both CBs and IBs are identical in design, which can be related to the development of policy IBs aligned with the CB regulatory system. Nevertheless, the significance of the oil and Arab springs shock was more evident to our analysis than to financial intermediation in central banks. Moreover, sustainable profit may be seen to be greater than CBs for IB identification, given that the shock equilibrium modulation of IBs is higher than CBs. Therefore, our study shows that a prudent macro regulation of GCC countries may be utilized through an oil-price shock. For the government leaders, lenders, analysts and scholars, our findings are useful in making their decisions by forecasting the potential productivity patterns in the GCC countries both for traditional and Islamic banks.

The rest of the paper is organized as follows. Section 2 review the literature and Section 3 discusses the data and research methodology. Section 4 discusses the empirical findings and draws inference. Section 5 concludes and discusses. 


\section{Literature Review}

Over recent decades, numerous reports have been carried out on factors that influence commercial banks' profitability. There are, however, several reports on the determinants of competitiveness of the Islamic economy. Banking profitability is an important tool in the evaluation of banking operations and in the planning and analysis of management [4]. Banks support economic prosperity, and the macro economy would be high if the bank works efficiently. A good positive association was observed between profitability and access to the credit danger in [5-8]. Thus, the greater the profitability of banks when debtors are willing to pay off their debts and profits (interest). The proportion of capital adequacy ratio (CAR), the bank's factors and macroeconomic variables [9] are linked favorably to statistical value.

The ISB profitability literature is, on the other hand, limited, because Islamic financial institutions is recent for the financial industry and requires specific information. However the uncertainty of ISB profits using return on equity as a metric of efficiencies and return on assets as a measure of profitability was examined in a paper prepared by [10]. The ROE, ROA, and NIM indices are evaluated by comparing for two banks, according to [5]. To create an ordinary small square, we use data at bank levels across the GCC countries. The results of the study show that there are relations between the characteristics with banks and conventional bank profitability indicators. GDP development has an impact on the competitiveness of Islamic banks as a significant macro-economic measure.

In a comparative analysis of CB and IB with a CAMEL test, ISBs have been recorded on better performance with regard to sufficient resources and liquidity, as compared to modern banks [11], which was compatible with the tests $[7,12]$. Some studies have shown that the relation between liquidity and profitability is significantly positive $[8,13]$. Others noted that ISB in Malaysia could not depend on stock efficiency to improve productivity [8]. Others noted harmful relationships. The results show that operating ratios show that traditional banks are generally operating at higher and better ratios than Islamic banks in GCC countries [5]. Islamic banks, though, have increased asset return (ROA) and dividends paid out. Finally, total costs in conventional banks are high and have an impact on profitability. The size of the bank is vital to the profitability of the bank [4]. Depending on the increased interest income in asset value, the bank's profitability will significantly raise, thereby increasing the bank's revenues and stock prices [14].

In IBs, operating profits rose faster than in conventional banks [1]. In contrast to conventional banks, IBs have a higher investment return. IB are profitable but probably not so efficient [15] as conventional banks. ISB are under the pressure of liquidity, according to [16]. CB, on the other hand, rely more so than Islamic banks on external liabilities. The relationship between the ISB and its determinants is investigated in a study carried out by Hutapea et al. [17] and compared to the conventional banks' range in Indonesia. In addition to adapting to higher revenue from the adaption of acquisitions to produce further earnings and revenues, certain businesses face a low discount rate for their potential cash flows and rising stock prices [18]. The findings showed that the CB margin reacts positively with increased interest rate fluctuations and the Islamic banking margin reacts negatively. An examination by CB in Indonesia of both the national preventive mechanism of the Islamic banks and NIM. Results revealed that avoidance, financial leverage, implied risks and nonperformance of loans impact NIM's (or NPM's) interest beyond consideration.

In ISB operating profits rose faster than in CB [1]. In contrast to $C B$, ISB have a better return on investment. ISB are less susceptible to liquidity risk, according to [16]. $\mathrm{CB}$, on the other hand, rely more than Islamic banks on external liabilities. The relationship between the ISB margins and their determinants was investigated in a study by Hutapea et al. [17] and compared to the Indonesian CB margin. The results indicated that the traditional banking margin reacts positively with greater fluctuations in interest rates and the ISB margin reacts negatively.

As the ISB differs from that of $C B$, the implications of the global financial crisis are expected [19]. The impact of oil price levels on banks' profits before the crisis was significantly positive, but the connection between price of oil and banks' performance was distorted after the global 
finance crisis. Following the crisis there has been no longer a significant relationship between oil prices and equity returns. This study of Hasan et al. [19] also showed that after the financial crisis both banks were affected differently.

Many previous studies examined the impact of oil price on economic growth. In order to explore the impact of oil price shocks on exchange rates and overall economy, Yoshizaki et al. [20] expand their Killian approach (2009), examining the impact of oil price shocks on GDP and US consumer price index. They found that oil price shock in oil-rich countries had no long-term impact. Berument et al. [21] explained that shocks in oil price impact the growth of most of the oil-exporting economies significantly and statistically. The study conducted by Gazdar et al. [22] revealed that the terms trade fluctuations and economic growth are significantly linked. In the GCC countries, oil prices remain one of the main drivers of profitability [23]. It shows that the development of the Islamic financial system supports trade fluctuations in petroleum growth over growth. Further, the study by Al-Khazali et al. [24] analyzes how oil prices move into bank loans. They are disturbed. The study showed that the impact of shocks in oil prices in large banks is more marked. Similar analysis was made by Lee [25] studying the shocks of oil price on Chinese banks and finding that higher oil prices have triggered a decline in the output of banking.

Nevertheless, it is in the light of the studies above that this study intends to fill the gaps by investigating on both Islamic and conventional banking and using (ROA, ROE), and (NIM Conventional banks and NPM Islamic banks) as indicators of bank profitability in GCC region, while some selected bank-specific variables and macroeconomic variables were utilized.

\section{Data and Methodology}

\subsection{Data}

The data used in our paper are panel data that comprise of Twenty (20) banks for each of Conventional and Islamic banks and cover the period from 2008 to 2017. The period of study started in 2008 and finished in 2017 to cover years before and after the events of Arab revolutions and oil price shocks which are helpful to figure out whether there is any change in the profitability for both Islamic and conventional banks. Meanwhile, in order to enhance the efficiency of the time series, due to the short span of the series available, the data are converted from annual to quarterly series by using the interpolation approach. We note that we have some quarterly data, for example, Inflation, Oil prices, and GDP and some annual data. It is common to conduct interpretation to convert the annual data to quarterly data in this situation, see, for example, [26,27]. In this paper, we follow their approach to converting all our annual data to quarterly.

In this study, we consider both bank-specific and macroeconomic variables to determine the bank profitability in both (CBs) and (IBs) from GCC countries. The bank profitability was measured by using three indicators, which are (ROA), (ROE), and (NIM) for conventional banks, while ROA, $\mathrm{ROE}$, and (NPM) are utilized for Islamic banks as profitability indicators. As for the bank-specific variables, credit risk (CR), capital adequacy ratio (CAR), and leverage (LEV) are used, and inflation (INF), gross domestic product (GDP), and oil price are employed as control variables. Moreover, in order to ensure the robustness of our estimation, we factor in the oil price shock and the Arab Spring by creating two dummy variables: Dum_op for oil price fall and Dum_as for the Arab spring. The bank profitability indicators and bank-specific variables are obtained from Orbis/Bureau van Dijk (2019) and bank statements, inflation (INF) and gross domestic product are obtained from World Bank Development indicator (2019), while data for oil price (OP) are sourced from OPEC (2019). We summarize the variables used in our paper in Table 1. 
Table 1. Description of variables and sources.

\begin{tabular}{cccc}
\hline Symbol & Variables & Proxy & Source \\
\hline ROA & Return On Assets & $\begin{array}{c}\text { Net income after tax before unusual items } \\
\text { as percentage of total assets (\%) }\end{array}$ & Orbis/Bureau van Dijk \\
\hline ROE & Return On Equity & $\begin{array}{c}\text { Net income after tax before unusual items } \\
\text { as percentage of shareholders' equity (\%) }\end{array}$ & Orbis/Bureau van Dijk \\
\hline NIM & Net Interest Margin & $\begin{array}{c}\text { Alteration amid interest revenue and interest } \\
\text { expense relative to the amount of assets (\%) }\end{array}$ & Orbis/Bureau van Dijk \\
\hline NPM & Net Profit Margin & $\begin{array}{c}\text { Net-financing income } \text { (income of financing (-) } \\
\text { income distributed to depositors)/total assets (\%) }\end{array}$ & Orbis/Bureau van Dijk \\
\hline CAR & Capital Adequacy Ratio & Bndependent Variables: & Tonk Specific Variables: \\
\hline LEV & Leverage & Total liabilities/Total Equity & Orbis/Bureau van Dijk \\
\hline CR & Credit Risk & Loans/Total Assets (\%) & Orbis/Bureau van Dijk \\
\hline INF & Inflation rate & Macroeconomic Variables: & World Bank \\
\hline OILP & Oil Price & Annual inflation based on consumer price index & OPEC \\
\hline GDP & Gross Domestic Product Growth (annual \%) & Real price of OPEC basket (USD billion) & World Bank \\
\hline
\end{tabular}

\subsection{Methodology}

Our study examines the effect of bank variables and macroeconomic variables on bank profitability using the theoretical framework derived from previous studies. To do this, we first use [28]'s Grouped Average Approach for frame data in the ARDL panel framework. In order to examine the static characteristics of the variables in our model, we use unit root tests developed by Levin et al. [29] and Im et al. [30]. LLC is next used for testing the intersection root of the board cross-sections. For each individual variable the IPS test is applied to test the root of the unit. References [31,32] have asserted that many studies dedicate a Type 1 error by refusing a non-co-integration presumption as it was found that most of the co-integration residual testing expects short-term parameters considered to have equal levels with the long-term variables. In the light of the argument, we use the structural-based co-integration test based on Westerlund's error correction [31] rather than the dynamic residual that doesn't impose any co-factor constraints on the long-term relationship between the variables within the model. In the end, we use techniques developed by ARDL's team estimate by [28].

We use twenty-four models in order to determine the impact of the banks and macroeconomic variables on the competitiveness of mainstream and Islamic Banks in the countries of the GCC. Three models with each indication of profitability relative to the dependent variable are estimated for both conventional and Islamic banks. The dummy variable (Dum op) is also entered and iterates all dependent variables and banks of all kinds. We have also provided both Dum op and Dum as for verification of the impact on conventional and IB, respectively, caused by the Arab revolutions and oil price shocks. Thus, the model is derived from [28] to use the following models:

$$
\begin{aligned}
& \Delta \mathrm{ROA}=\alpha_{\mathrm{i}}+\sum_{j=1}^{p-1} \beta_{\mathrm{i} 1} \Delta \mathrm{ROAb}_{\mathrm{it}}+\sum_{i=0}^{q-1} \beta_{\mathrm{i} 2} \Delta \mathrm{CR}_{\mathrm{kit}}+\sum_{i=0}^{q-1} \beta_{\mathrm{i} 3} \Delta \mathrm{CAR}_{\mathrm{eit}} \\
& \quad+\sum_{i=1}^{q-1} \beta_{\mathrm{i} 4} \Delta \mathrm{LEV}_{\mathrm{cit}}+\sum_{i=1}^{q-1} \beta_{\mathrm{i} 5} \Delta \mathrm{INF}_{\mathrm{dit}}+\sum_{i=1}^{q-1} \beta \mathrm{i} 6 \Delta \mathrm{GDP}_{\mathrm{eit}}+\sum_{i=1}^{q-1} \beta_{\mathrm{i} 7} \Delta \mathrm{OP}_{\mathrm{vit}}+\varepsilon_{\mathrm{it}} \\
& \mathrm{ROE}=\alpha_{\mathrm{i}}+\sum_{j=1}^{p-1} \beta_{\mathrm{i} 1} \Delta \mathrm{ROEb}_{\mathrm{it}}+\sum_{i=0}^{q-1} \beta_{\mathrm{i} 2} \Delta \mathrm{CR}_{\mathrm{kit}}+\sum_{i=0}^{q-1} \beta_{\mathrm{i} 3} \Delta \mathrm{CAR}_{\mathrm{eit}}+\sum_{i=1}^{q-1} \beta_{\mathrm{i} 4} \Delta \mathrm{LEV}_{\mathrm{cit}} \\
& +\sum_{i=1}^{q-1} \beta_{\mathrm{i} 5} \Delta \mathrm{INF}_{\mathrm{dit}}+\sum_{i=1}^{q-1} \beta \mathrm{i} 6 \Delta \mathrm{GDP}_{\mathrm{eit}}+\sum_{i=1}^{q-1} \beta_{\mathrm{i} 7} \Delta \mathrm{OP}_{\mathrm{vit}}+\varepsilon_{\mathrm{it}} \\
& \Delta \mathrm{NIM}=\alpha_{\mathrm{i}}+\sum_{j=1}^{p-1} \beta_{\mathrm{i} 1} \Delta \mathrm{NIMb}_{\mathrm{it}}+\sum_{i=0}^{q-1} \beta_{\mathrm{i} 2} \Delta \mathrm{CR}_{\mathrm{kit}}+\sum_{i=0}^{q-1} \beta_{\mathrm{i} 3} \Delta \mathrm{CAR}_{\mathrm{eit}}+\sum_{i=1}^{q-1} \beta_{\mathrm{i} 4} \Delta \mathrm{LEV}_{\mathrm{cit}} \\
& +\sum_{i=1}^{q-1} \beta_{\mathrm{i} 5} \Delta \mathrm{INF}_{\mathrm{dit}}+\sum_{i=1}^{q-1} \beta \mathrm{in}_{6} \Delta \mathrm{GDP}_{\mathrm{eit}}+\sum_{i=1}^{q-1} \beta_{\mathrm{i} 7} \Delta \mathrm{OP}_{\mathrm{vit}}+\varepsilon_{\mathrm{it}} \\
& \Delta \mathrm{NPM}=\alpha_{\mathrm{i}}+\sum_{j=1}^{p-1} \beta_{\mathrm{i} 1} \Delta \mathrm{NPMb}_{\mathrm{it}}+\sum_{i=0}^{q-1} \beta_{\mathrm{i} 2} \Delta \mathrm{CR}_{\mathrm{kit}}+\sum_{i=0}^{q-1} \beta_{\mathrm{i} 3} \Delta \mathrm{CAR}_{\mathrm{eit}}+\sum_{i=1}^{q-1} \beta_{\mathrm{i} 4} \Delta \mathrm{LEV}_{\mathrm{cit}} \\
& +\sum_{i=1}^{q-1} \beta_{\mathrm{i} 5} \Delta \mathrm{INF}_{\mathrm{dit}}+\sum_{i=1}^{q-1} \beta \mathrm{i} 6 \Delta \mathrm{GDP}_{\mathrm{eit}}+\sum_{i=1}^{q-1} \beta_{\mathrm{i} 7} \Delta \mathrm{OP}_{\mathrm{vit}}+\varepsilon_{\mathrm{it}}
\end{aligned}
$$


where ROA, ROE, NIM, and NPM (returns on assets, returns on equity, net interest profit margin and net profit margin) are endogenous variables, CR, CAR, LEV, INF, GDP and OP (credit risk, capital adequacy ratio, leverage, inflation, gross domestic product, and oil price) are exogenous variables, $\Delta$ is the first difference operator, $\alpha 1$ represents a country-specific intercept, $\mathrm{p}$, $\mathrm{q}$ are optimal lag which the framework permits to have different lag order, $\beta_{i j}(j=1, \ldots, 7)$ are the short-run coefficient, $\lambda_{j}(j=1, \ldots, 7)$ are the long-run coefficients, $\mathrm{i}$ is the specific unit, $\mathrm{t}$ is the time trend, and $\varepsilon_{\mathrm{it}}$ is the error term. Besides, we assume a long-run relationship in our models and include the error correction model to improve the ARDL framework as presented in Equations (1)-(4).

Where the $E C T_{\mathrm{t}-1}$ is the error term specified for the long-run equilibrium relationship, and $a, b, c, d$ represent the speeds of convergence in case of any shock to the system.

\section{Empirical Findings}

\subsection{Descriptive Statistics}

Table 2 shows the descriptive statistics. The table shows that both types of banks have the same mean interval, ensuring common features between the banks of the GCC countries. Meanwhile, the variables' standard deviations for both types of banks are not high, inferring that the data are dispersed relatively close to the mean and their dispersion is normal.

Table 2. Descriptive statistics of the variables.

\begin{tabular}{|c|c|c|c|c|c|c|c|c|c|c|c|c|}
\hline \multirow[b]{2}{*}{ Variable } & \multicolumn{5}{|c|}{ Conventional Banks } & \multicolumn{7}{|c|}{ Islamic Banks } \\
\hline & Obs & Mean & Std.Dev & Min. & $\operatorname{Max}$ & $\begin{array}{c}\mathrm{JB} \\
p \text {-Value }\end{array}$ & Obs & Mean & Std.Dev & Min. & $\operatorname{Max}$ & $\underset{p \text {-Value }}{\text { JB }}$ \\
\hline ROE & 800 & 0.016 & 0.173 & -2.52 & 0.39 & 0.075 & 800 & 0.033 & 0.035 & -0.16 & 0.15 & 0.061 \\
\hline $\mathrm{ROA}$ & 800 & 0.004 & 0.003 & -0.02 & 0.008 & 0.251 & 800 & 0.049 & 0.63 & -1.36 & 9.27 & 0.922 \\
\hline NIM/NPM & 800 & 0.66 & 0.14 & 0.33 & 1.13 & 0.0000 & 800 & 0.88 & 0.48 & 0.11 & 2.86 & 0.0000 \\
\hline $\mathrm{CR}$ & 800 & 0.15 & 0.026 & 0.06 & 0.22 & 0.132 & 800 & 0.13 & 0.06 & -0.02 & 0.61 & 0.132 \\
\hline CAR & 800 & 0.03 & 0.01 & 0 & 0.1 & 0.101 & 800 & 0.04 & 0.03 & 0 & 0.28 & 0.502 \\
\hline LEV & 800 & 1.91 & 2.45 & -3.39 & 34.26 & 0.0510 & 800 & 1.38 & 0.66 & -0.25 & 3.85 & 0.010 \\
\hline INF & 800 & 0.75 & 0.86 & -1.86 & 4.61 & 0.0000 & 800 & 0.77 & 0.85 & -1.86 & 4.61 & 0.231 \\
\hline GDP & 800 & 0.97 & 1.21 & -1.96 & 5.03 & 0.656 & 800 & 0.98 & 1.22 & -1.96 & 5.03 & 0.022 \\
\hline OP (Billion US\$) & 800 & 19.82 & 6.42 & 8.7 & 30.87 & 0.192 & 800 & 19.79 & 6.43 & 8.7 & 30.87 & 0.898 \\
\hline
\end{tabular}

Table 3 shows the selection of the 20 Conventional and 20 Islamic banks from GCC countries with the exemption of Oman. Oman has been exempted because the Islamic banking system only starts in the country from year 2011. Moreover, the selection of the conventional and Islamic banks from the remaining five GCC countries are based on the banks listed in the stock market with data availability.

Table 3. Sample Banks by Country and type.

\begin{tabular}{cccc}
\hline Country & Conventional Bank & Islamic Bank & Total \\
\hline UAE & 6 & 5 & 11 \\
\hline Qatar & 4 & 4 & 8 \\
\hline Bahrain & 3 & 3 & 6 \\
\hline Kuwait & 4 & 4 & 8 \\
\hline Saudi & 3 & 4 & 7 \\
\hline Total & 20 & 20 & 40
\end{tabular}




\subsection{Unit Root Test}

The variables of the ARDL panel may be a mixed command component, i.e., I(0) or I(1); but, their predictive potential should not remain lost $[28,32,33]$. In order to escape the issue of marginal slope, the unit root must be followed by some empiric estimate [34]. While some study has shown the lack of unit root test pre-estimation for ARDL technologies, both LLC and IPS root tests have been used in our study, to ensure there are no variables in our model I (2), and therefore the model which we have used is valid [28]. In this study, we do so in general. Table 4 shows the results. The LLC test confirms that both conventional and Islamic banks have constant variables. The IPS test, on the other hand, shows that, with the exception of the leverage and oil price, the majority of the variables are fixed and fixed at the first difference for the conventional bank. The IPS test shows, however, that all variables are instable on the level, with the exception of constant inflation at the level of Islamist banks, and are fixed at the first difference. In brief, it is obvious from the two experiments that either $\mathrm{I}(0)$ or $\mathrm{I}(1)$ are the variables in our model and not I(2), indicating that the model we have used during our study is the correct one.

Table 4. Unit root test.

\begin{tabular}{|c|c|c|c|c|c|c|c|c|}
\hline & \multicolumn{4}{|c|}{ Conventional Banks } & \multicolumn{4}{|c|}{ Islamic Banks } \\
\hline & Common & it Root & Individual & Unit Root & Common & it Root & Individua & Unit Root \\
\hline \multirow[t]{2}{*}{ Variable } & \multicolumn{2}{|c|}{ LLC $t^{*}$-Stat. } & \multicolumn{2}{|c|}{ IPS W-t-Bar Stat } & \multicolumn{2}{|c|}{ LLC $t$ *-Stat. } & \multicolumn{2}{|c|}{ IPS W-t-Bar Stat } \\
\hline & Level & 1st Diff. & Level & 1st Diff. & Level & 1st Diff. & Level & 1st Diff. \\
\hline ROE & $-4.98^{* * *}$ & - & $-5.69 * * *$ & - & $-3.86^{* * *}$ & - & -1.74 & $-5.09 * * *$ \\
\hline ROA & $-2.16^{* *}$ & - & $-5.04 * * *$ & - & $-6.15^{* * *}$ & - & -1.71 & $-3.59 * * *$ \\
\hline NIM/NPM & $-4.95^{* * *}$ & - & $-4.14^{* * *}$ & - & $-6.39 * * *$ & - & -1.72 & $-3.59 * * *$ \\
\hline $\mathrm{CR}$ & $-2.26^{* *}$ & - & $-2.42 * * *$ & - & $-4.69^{* * *}$ & - & -1.28 & $-4.16^{* * *}$ \\
\hline CAR & $-2.32 * * *$ & - & $-1.48^{* * *}$ & - & $-4.81^{* * *}$ & - & -1.62 & $-5.34 * * *$ \\
\hline Inflation & $-10.82 * * *$ & - & $-9.13 * * *$ & - & $-10.67^{* * *}$ & - & $-2.57^{* * *}$ & - \\
\hline GDP & $-5.89^{* * *}$ & - & $-2.94 * * *$ & & $-5.99^{* * *}$ & - & -1.49 & $-3.72 * * *$ \\
\hline Leverage & $-2.74 * * *$ & - & -1.03 & $-3.48^{* * *}$ & $-3.21 * * *$ & - & -1.04 & $-3.76^{* *}$ \\
\hline Oil Price & $-2.69 * * *$ & - & -0.94 & $-3.04^{* * *}$ & $-2.68^{* * *}$ & - & -0.93 & $-3.03^{* * *}$ \\
\hline
\end{tabular}

Ho: Panels contain unit roots. ${ }^{* * *}, * *$, and ${ }^{*}$ indicate $1 \%, 5 \%$, and $10 \%$ significance level, respectively.

\subsection{Westerlund Panel Cointegration Testing}

We perform a joint integration study utilizing the Westerlund Integration Test (208) to maintain a consistent long-term equilibrium between the variables of our models in order to prevent having a false gradient in our estimation. The integration test of the Westerlund board consists of four tests for the common integration test. The first two (Gt and Ga) tests are used to test the null hypothesis with no common integration and the remaining two tests ( $\mathrm{Pt}$ and $\mathrm{Pa}$ ), which are combining in at least one unit, to test the alternative hypothesis. The results of our estimate as illustrated in Table 5 show that the ROA integration test as a dependent variable indicates a long-term integrative relationship between the CB and IB variables. This is the product of three tests which reject the zero hypothesis and suggest that a long-term relationship exists. Likewise, the return on the equity model as a dependent variable indicates a long-term relationship among traditional and Islamic banks since the results of Table 5 suggest that all the four tests were statistically relevant and the blank dismissed the hypothesis that the variables were not combined. Nevertheless, while the findings of the Type 3 (NIM/NPM as dependent variable) declined to reject two of the four measures of the null hypothesis that traditional banks were not jointly combined, only one did not refute the null hypothesis that an Islamic bank was not co-integrated. In short, the Westerlund Integration Panel Check demonstrates that the variables in our models are complementary. 
Table 5. Westerlund Cointegration test.

\begin{tabular}{|c|c|c|c|c|c|c|}
\hline \multirow[b]{3}{*}{ Test } & \multicolumn{3}{|c|}{ Conventional Banks } & \multicolumn{3}{|c|}{ Islamic Banks } \\
\hline & \multicolumn{3}{|c|}{ Value } & \multicolumn{3}{|c|}{ Value } \\
\hline & ROA & ROE & NIM & ROA & ROE & NPM \\
\hline $\mathrm{G}_{\mathrm{t}}$ & -2.137 & $-2.731^{* *}$ & -1.823 & -1.606 & $-2.309 *$ & -1.418 \\
\hline $\mathrm{G}_{\mathrm{a}}$ & $-5.817^{*}$ & $-7.603^{*}$ & $-5.741^{* *}$ & $-5.212^{* *}$ & $-7.408^{* * *}$ & $-3.554 *$ \\
\hline $\mathrm{P}_{\mathrm{t}}$ & $-9.478^{* *}$ & $-6.868^{*}$ & -5.842 & $-4.036^{*}$ & $-6.475^{* *}$ & $-7.554^{* * *}$ \\
\hline $\mathrm{P}_{\mathrm{a}}$ & $5.211^{* * *}$ & $-4.198 *$ & $-4.428^{* *}$ & $-2.517^{* *}$ & $-3.517^{* *}$ & $-4.212^{* *}$ \\
\hline
\end{tabular}

Ho: No Cointegration. ${ }^{* * *}, * *$, and ${ }^{*}$ indicate $1 \%, 5 \%$, and $10 \%$ significance level, respectively.

\subsection{Long and Short-Run Causal Relationship}

We present in Table 6 the results for both long and short-run causal relationships among the bank-specific variables, macroeconomic variables, and bank profitability indicators for both Conventional and Islamic banks. From Table 6, we confirm that CR has a long-run positive causal relationship between ROA ROE and NIM/NPM for both Conventional and Islamic bank.

Table 6. Long and Short-run estimates.

\begin{tabular}{|c|c|c|c|c|c|c|}
\hline \multirow[b]{2}{*}{ Dep. Variable } & \multicolumn{3}{|c|}{ Conventional Banks } & \multicolumn{3}{|c|}{ Islamic Banks } \\
\hline & $\begin{array}{c}\text { ROA } \\
\text { (Model 1) }\end{array}$ & $\begin{array}{c}\text { ROE } \\
\text { (Model 2) }\end{array}$ & $\begin{array}{c}\text { NIM } \\
\text { (Model 3) }\end{array}$ & $\begin{array}{c}\text { ROA } \\
\text { (Model 4) }\end{array}$ & $\begin{array}{c}\text { ROE } \\
\text { (Model 5) }\end{array}$ & $\begin{array}{c}\text { NPM } \\
\text { (Model 6) }\end{array}$ \\
\hline \multicolumn{7}{|l|}{ Long-run coef. } \\
\hline$C R$ & $0.011^{* * *}$ & $5.58^{* *}$ & $8.94^{* * *}$ & $11.53^{* * *}$ & $0.69^{* * *}$ & $3.85 * * *$ \\
\hline$C A R$ & $-0.70^{* * *}$ & $5.71^{* *}$ & $-4.103 *$ & $1.71^{* *}$ & $-1.82 *$ & $5.71^{* * *}$ \\
\hline LEV & $-0.0006^{* * *}$ & $-0.032 * *$ & -0.005 & $-0.80 * * *$ & 0.003 & $-0.02 *$ \\
\hline INF & -0.0001 & $-0.074^{* * *}$ & $-0.09 * * *$ & $0.065^{* * *}$ & $-0.26^{* * *}$ & $0.135^{* * *}$ \\
\hline GDP & $-0.0003^{* * *}$ & 0.007 & $0.03^{* * *}$ & -0.006 & $0.14^{* * *}$ & 0.009 \\
\hline$O P$ & -0.00029 & $-0.012^{* * *}$ & $-0.002 *$ & -0.0009 & $0.014^{* * *}$ & $-0.009 * * *$ \\
\hline \multicolumn{7}{|l|}{ Short-run coef. } \\
\hline$E C T$ & $-0.045^{* *}$ & -0.001 & $-0.06^{* *}$ & $-0.010^{*}$ & $-0.011^{* *}$ & $-0.034 *$ \\
\hline$\Delta C R$ & 0.009 & 0.045 & -0.21 & 1.32 & 0.139 & 4.48 \\
\hline$\triangle C A R$ & -0.051 & 0.26 & 17.67 & -5.36 & 1.09 & 6.40 \\
\hline$\triangle L E V$ & -0.0008 & 0.004 & -0.001 & -0.17 & 0.011 & -0.164 \\
\hline$\triangle I N F$ & 0.00009 & 0.003 & -0.01 & -0.017 & -0.005 & 0.074 \\
\hline$\triangle G D P$ & 0.0003 & -0.0002 & -0.01 & 0.010 & 0.005 & -0.032 \\
\hline$\triangle O P$ & 0.0002 & 0.0004 * & 0.003 & 0.001 & 0.0002 & 0.006 \\
\hline
\end{tabular}

Note: ROA = Returns on assets, ROE = Returns on equity, NIM = Net interest margin, NPM = Net profit margin, $\mathrm{CR}=$ Credit risk, $\mathrm{CAR}=$ Capital adequacy ratio, $\mathrm{LEV}=$ Leverage, $\mathrm{INF}=$ Inflation, GDP $=$ Gross domestic product, $\mathrm{OP}=$ Oil price. ${ }^{* * *},{ }^{* *}$, and ${ }^{*}$ indicates $1 \%, 5 \%$, and $10 \%$ significance level, respectively.

The short and long-run effects were estimated in this study because both macroeconomics and bank-specific variables employed in this study are believed to have a time horizon that makes some of the inflexible (short run), and those that have time to adjust (long-run). Therefore, in this time horizon, we envisage some impact on the bank profitability, which then make this kind of estimation to be imperative. It will serve as a guide for the policy makers to have a deeper understanding of which of the variables ha a significant effect on bank profitability, either in the short or long-run.

The long-run causal impact estimated result as presented in Table 6 reveal that in Model 1, 2 and 3 (conventional banks), CR, CAR, LEV, and GDP were found to have significant long-run impacts of ROA,; CR, CAR, LEV, INF, and OP show a significant impact on ROE. While, CR, CAR, INF, GDP, 
and OP reveal significant influences on NIM. Similarly, for Islamic banks (Model 4, 5, and 6), CR, CAR, LEV, and INF were found to impact on ROA significantly. ROE was found to be significantly influenced by CR, CAR, INF, GDP and OP; while CR, CAR, LEV, INF and OP were found to have significant impact on NPM.

Our findings consistent with those from References $[8,35,36]$, who found the positive influence from credit risk to the asset performance of a bank; also Alfadli et al. [23], found that credit risk demonstrated that safety further contributes to profitability and has re-emerged as a critical variable in the banking sector. Meanwhile, LEV is found to have a negative and significant causal relationship with ROA for both Conventional and Islamic banks. Our finding gives credence to some previous studies who had earlier found similar results in their works. References [37-39], revealed that leverage ratio is negatively related to banks profitability.

As for CAR, while a negative causal relationship is found between ROA and CAR for Conventional banks, a positive and significant causal relationship was found for an Islamic bank. The negative result found for CB is in agreement with the study of References [39-41], who argued that there is a possibility for capital adequacy ratio to have a perverse effect on bank profitability. The negative result is also an indication that capital infusion would have reduced the bank's profit in the long-run; this is in line with finance theory which identifies capital as a high-cost financing mode that decreases profits of the bank. It is an indication that CBs should not extensively strengthen their capital base as it debases long-term profitability. Meanwhile the positive result found for IB is in agreement with some previous studies [9,42], who found positive influence of capital ratio on bank profitability. In other words, it is an indication that IBs have enough capital bases to protect the depositor's money, and this view corroborates Karim et al. [43] and Bitar et al. [44]. Meanwhile, the negative and positive influence of capital ratio on ROA found in this study for both CBs and IBs is in contrast to the study of Almaqtari et al. [37], who failed to establish any significant relationship between CAR and ROA. Moreover, the non-significance of the causal relationship between INF and ROA is in agreement with Bucevska et al. [45], while the positive and significant relationship found for Islamic bank is in line with References $[4,40,46]$.

GDP is found to have a negative and significant influence on ROA in CBs, but found not to influence ROA in IBs which is in agreement with References $[36,40,47]$. This result found to be in line with the findings of References [35,48,49].

As for the short-run causal relationship, none of the variables is found to be sensitive to ROA in the short-run. Meanwhile, the ECT coefficients for models 1 and 4 are found to be negative and significant at 5\% confidence level, which is an indication that in both Conventional and Islamic banks, there will be convergence to the equilibrium in the presence of shock. The ECT coefficients also indicate that in case of any shock, the model will return back to the equilibrium at $45 \%$ and $11 \%$ adjustment speed rate for both Conventional and Islamic banks, respectively.

The result as summarized in Table 6 further shows that for models 2 and 5, CR, CAR, LEV, INF and OP are found to have a causal influence on efficiency of CBs at the long-run, while CR, CAR, INF, GDP, and OP are found to influence IBs efficiency at the long-run. The results of the positive influence of credit risk and the negative impact of inflation on returns on assets are in agreement with findings of Ali et al. [35]. Meanwhile, the negative influence of INF found in our study corroborates Adusei et al. [46]. The positive impact of GDP on ROE found for IBs is in agreement with Yahya et al. [39], while it's in contrast to References [37,48-50]. Moreover, the ECT coefficient for IBs is found to be negative and significance at 5\% confidence which is good for convergence in case of shock, while ECT for CBs is found not to be significant. The implication of the significance of ECT coefficient for IBs banks is that in the presence of shock, the model will converge back to equilibrium at the speed rate of $11 \%$, and more so, the result indicates that there is a stable long-run relationship between ROE and those variables that are statistically significant at the long-run.

The result for models3 and 6 indicates that while CR, CAR, INF, GDP and OP influence net interest margin for $\mathrm{CBs}, \mathrm{CR}, \mathrm{CAR}, \mathrm{LEV}$, and $\mathrm{OP}$ is found to influence net profit margin for IBs. This implies 
that those bank-specific economic variables influence both the NIM/NPM in the long-run. Meanwhile, both models are found to have negative and significant ECT coefficients which are an indication that in the presence of shock, both models can converge back to equilibrium at the speed rates of $6 \%$ and $34 \%$, respectively. The significance of the ECT also implies a stable long-run relationship exists between those bank-specific and macroeconomic variables that are found to be statistically significant and NIM/NPM. The oil price found to be significant in our study is contradicted by Yanikkaya et al. [51], who could not find a relationship between them. Meanwhile, the significant influence of leverage on NPM, found for IB, contrast the finding of Sigmund et al. [52], who could not find a significant relationship in a similar study. Sun et al. [53], in their study found no relationship between capital ratio and net interest margin for CBs and net profit margin for IBs in their study to determine the driving bank performance in OIC countries, hence in contrast with our findings that shows an existence of causal relationship between capital adequacy and NIM for CBs, and between NPM for IBs. The positive influence of inflation on NPM for IBs corroborates the work of Knezevic et al. [54], but disagrees with the study on its finding of no causal relationship between economic growth and NIM for CBs. In summary, inference from our study findings indicates that the bank-specific and macroeconomic variables employed in our study do have a significant influence on the bank profitability for both CBs and IBs.

\subsection{Robustness Check Controlling for the Arab Spring}

In order to examine if the Arab Spring occurrence influenced significantly the CBs and IBs profitability in the GCC region, a dummy variable was created by assigning 0 to the period before the event and 1 to the period after. The dummy variable (Dum_as) is then added to the model and estimated. The results are summarized and presented in Table 7 . The results as presented in Table 7 reveals that the Arab Spring influence negatively the returns on assets for the CBs while the negative influence on IBs is found not to be significant. Similarly, the Arab Spring shows a long-run causal relationship with ROA, ROE, and NIM in CBs, while the influence was only found on ROE and NPM for IBs. Meanwhile, CBs shows sign of convergence to equilibrium in case of a shock for models 7 and 9 for CBs, while only model 11 for IBs will be able to return back to equilibrium in case of shock-like Arab spring. This could imply that because the IBs are an interest-free bank and as such its effectiveness of the bank assets might not be influenced by the crises. This could corroborate the view of Bitar et al. [44], who opined that Islamic banks are superior to CBs in terms of capitalization. Meanwhile, the Arab Spring is found from our result as presented in Table 7 to have a significant strong influence on the net interest margin of the CBs because the short and long-run coefficient is found to be significant, while is found to have a positive influence on the net profit margin for the IBs at the long-run. Also, the crisis was found to have a significant positive influence on returns on equity for CBs and IBs in the long-run. It is worthy to note that while the ECT coefficient shows there will be convergence for models 7 and 9 for $\mathrm{CB}$, only Model 11 will be converged to equilibrium in the presence of disequilibrium.

Table 7. Long and short-run estimates controlling for the Arab Spring.

\begin{tabular}{ccccccc}
\hline & \multicolumn{3}{c}{ Conventional Banks } & \multicolumn{3}{c}{ Islamic Banks } \\
\hline Dep. Variable & $\begin{array}{c}\text { ROA } \\
\text { (Model 7) }\end{array}$ & $\begin{array}{c}\text { ROE } \\
\text { (Model 8) }\end{array}$ & $\begin{array}{c}\text { NIM } \\
\text { (Model 9) }\end{array}$ & $\begin{array}{c}\text { ROA } \\
\text { (Model 10) }\end{array}$ & $\begin{array}{c}\text { ROE } \\
\text { (Model 11) }\end{array}$ & $\begin{array}{c}\text { NPM } \\
\text { (Model 12) }\end{array}$ \\
\hline Long-run coef. & & & & & \\
\hline$C R$ & -0.007 & $1.38^{* * *}$ & $3.21^{* * *}$ & 4.24 & 0.002 & $-1.51^{* * *}$ \\
\hline$C A R$ & 0.019 & $-5.70^{* * *}$ & $-4.67^{* *}$ & -4.02 & $-0.67^{* * *}$ & $8.28^{* * *}$ \\
\hline$L E V$ & $-0.005^{* * *}$ & $0.084^{* * *}$ & -0.005 & -0.05 & $-0.020^{* * *}$ & -0.0024 \\
\hline$I N F$ & $0.0003^{* * *}$ & $-0.017^{* * *}$ & $0.019^{* *}$ & 0.17 & $-0.002^{* * *}$ & $0.144^{* * *}$ \\
\hline$G D P$ & -0.0002 & $0.015^{* * *}$ & $-0.046^{* * *}$ & -0.26 & $0.005^{* * *}$ & $-0.074^{* * *}$ \\
\hline
\end{tabular}


Table 7. Cont.

\begin{tabular}{|c|c|c|c|c|c|c|}
\hline \multirow[b]{2}{*}{ Dep. Variable } & \multicolumn{3}{|c|}{ Conventional Banks } & \multicolumn{3}{|c|}{ Islamic Banks } \\
\hline & $\begin{array}{c}\text { ROA } \\
\text { (Model 7) }\end{array}$ & $\begin{array}{c}\text { ROE } \\
\text { (Model 8) }\end{array}$ & $\begin{array}{c}\text { NIM } \\
\text { (Model 9) }\end{array}$ & $\begin{array}{c}\text { ROA } \\
\text { (Model 10) }\end{array}$ & $\begin{array}{c}\text { ROE } \\
\text { (Model 11) }\end{array}$ & $\begin{array}{c}\text { NPM } \\
\text { (Model 12) }\end{array}$ \\
\hline$O P$ & $-0.0002^{* * *}$ & $-0.002^{* * *}$ & $-0.003^{* * *}$ & -0.032 & -0.0001 & 0.0007 \\
\hline Dum_as & $-0.002^{* * *}$ & $0.045^{* * *}$ & $0.279^{* * *}$ & -0.96 & $0.024^{* * *}$ & $0.524^{* * *}$ \\
\hline \multicolumn{7}{|l|}{ Short-run coef. } \\
\hline$E C T$ & $-0.045 *$ & -0.005 & $-0.093^{* * *}$ & -0.002 & $-0.065^{* * *}$ & -0.006 \\
\hline$\Delta C R$ & -0.003 & 0.027 & 0.069 & 1.39 & $0.22 * * *$ & $4.64 *$ \\
\hline$\triangle C A R$ & -0.062 & 0.508 & 17.85 & -4.69 & 0.621 & 4.77 \\
\hline$\triangle L E V$ & -0.002 & 0.006 & -0.081 & -0.16 & -0.008 & -0.198 \\
\hline$\Delta I N F$ & 0.0002 & 0.002 & -0.029 & -0.013 & 0.001 & 0.089 \\
\hline$\triangle G D P$ & 0.0007 & -0.0002 & 0.009 & 0.009 & 0.001 & -0.022 \\
\hline$\triangle O P$ & -0.00014 & 0.0003 & $0.004^{* *}$ & 0.001 & 0.0002 & 0.004 \\
\hline$\Delta D u m \_a s$ & $-0.0006^{*}$ & -0.0004 & $-0.011^{* *}$ & -0.002 & -0.0002 & -0.009 \\
\hline
\end{tabular}

Note: Note: $\mathrm{ROA}=$ Returns on assets, $\mathrm{ROE}=$ Returns on equity, NIM $=$ Net interest margin, NPM $=$ Net profit margin, $\mathrm{CR}=$ Credit risk, $\mathrm{CAR}=$ Capital adequacy ratio, $\mathrm{LEV}=$ Leverage, $\mathrm{INF}=$ Inflation, $\mathrm{GDP}=$ Gross domestic product, $\mathrm{OP}=$ Oil price. ${ }^{* * *},{ }^{* *}$, and ${ }^{*}$ indicates $1 \%, 5 \%$, and $10 \%$ significance level, respectively.

\subsection{Robustness Check Controlling for Oil Price fall}

Similar to the robustness check for the Arab spring, the shock of oil price was factored into the model. Dum_op takes a value of 1 after oil price fall and takes a value of 0 before oil price fall. This is because the economy of GCC countries mostly depends on oil, and the oil price has been fluctuating, thus need to examine its influence on bank profitability. The dummy variable (Dum_op) was added to the model and the results of the estimates are summarized and presented in Table 8 . The results show that most of the bank-specific variables and macroeconomic variables employed in this study are still found to be significant for both the CBs and IBs, which implies that there is no much difference in terms of the influence of the oil price fall on the two banks, even though they are different in structures and operations. Dum_op coefficient as it is revealed in Table 8 for both CBs and IBs depicts that the oil price fall has a significant positive impact on the ROA and NIM/NPM for both CBs and IBs. However, the ECT coefficient reveals that only IBs will experience convergence in the presence of shock, while convergence to equilibrium for CBs could not be established due to the non-significance of the ECT coefficient.

Table 8. Long and Short-run estimating, controlling for Oil price fall.

\begin{tabular}{|c|c|c|c|c|c|c|}
\hline \multirow[b]{2}{*}{ Dep. Variable } & \multicolumn{3}{|c|}{ Conventional Banks } & \multicolumn{3}{|c|}{ Islamic Banks } \\
\hline & $\begin{array}{c}\text { ROA } \\
\text { (Model 13) }\end{array}$ & $\begin{array}{c}\text { ROE } \\
\text { (Model 14) }\end{array}$ & $\begin{array}{c}\text { NIM } \\
\text { (Model 15) }\end{array}$ & $\begin{array}{c}\text { ROA } \\
\text { (Model 16) }\end{array}$ & $\begin{array}{c}\text { ROE } \\
\text { (Model 17) }\end{array}$ & $\begin{array}{c}\text { NPM } \\
\text { (Model 18) }\end{array}$ \\
\hline \multicolumn{7}{|l|}{ Long-run coef. } \\
\hline$C R$ & $-0.015 *$ & $-2.76^{* * *}$ & $22.06^{* * *}$ & $11.74^{* * *}$ & $0.703^{* *}$ & $-0.994^{* * *}$ \\
\hline$C A R$ & $0.20 * * *$ & $-7.05^{* *}$ & -0.545 & $2.35^{* * *}$ & $-1.76^{*}$ & $15.44^{* * *}$ \\
\hline$L E V$ & $-0.0003 * * *$ & 0.002 & $-0.013^{* *}$ & $-0.93^{* * *}$ & 0.004 & $0.411^{* * *}$ \\
\hline INF & $-0.0008^{* * *}$ & $-0.069^{* * *}$ & $-0.048^{* * *}$ & $0.053^{* * *}$ & $-0.26^{* * *}$ & $0.109^{* * *}$ \\
\hline GDP & $-0.0007^{* * *}$ & $-0.059 * * *$ & $0.059 * * *$ & $-0.02 *$ & $0.135^{* * *}$ & $0.141^{* * *}$ \\
\hline$O P$ & $0.00011^{* * *}$ & $0.009^{* * *}$ & 0.002 & $0.015^{* * *}$ & $0.014^{* * *}$ & $-0.010 *$ \\
\hline Dum_op & $0.0005^{* *}$ & 0.025 & $0.211^{* * *}$ & $0.27^{* * *}$ & -0.007 & $0.253^{* * *}$ \\
\hline
\end{tabular}


Table 8. Cont.

\begin{tabular}{ccccccc}
\hline & \multicolumn{3}{c}{ Conventional Banks } & \multicolumn{3}{c}{ Islamic Banks } \\
\hline Dep. Variable & $\begin{array}{c}\text { ROA } \\
\text { (Model 13) }\end{array}$ & $\begin{array}{c}\text { ROE } \\
\text { (Model 14) }\end{array}$ & $\begin{array}{c}\text { NIM } \\
\text { (Model 15) }\end{array}$ & $\begin{array}{c}\text { ROA } \\
\text { (Model 16) }\end{array}$ & $\begin{array}{c}\text { ROE } \\
\text { (Model 17) }\end{array}$ & $\begin{array}{c}\text { NPM } \\
\text { (Model 18) }\end{array}$ \\
\hline Short-run coef. & & & & & & \\
\hline$E C T$ & -0.019 & -0.002 & -0.014 & -0.010 & $-0.011^{* *}$ & $-0.035^{* *}$ \\
\hline$\Delta C R$ & 0.003 & 0.049 & 0.278 & 1.30 & 0.137 & 4.22 \\
\hline$\Delta C A R$ & -0.161 & 0.179 & 13.43 & -5.51 & 1.089 & 8.97 \\
\hline$\Delta L E V$ & -0.003 & -0.0002 & -0.072 & -0.166 & 0.011 & -0.116 \\
\hline$\Delta I N F$ & 0.0002 & 0.001 & -0.018 & -0.017 & -0.005 & 0.075 \\
\hline$\Delta G D P$ & -0.0004 & 0.0003 & -0.002 & 0.010 & 0.005 & -0.040 \\
\hline$\Delta O P$ & -0.0003 & $0.0003 *$ & $0.004 * *$ & 0.001 & 0.0002 & 0.006 \\
\hline$\Delta D$ * & -0.0003 & -0.0002 & -0.0005 & -0.005 & -0.0002 & -0.004 \\
\hline
\end{tabular}

Note: Note: ROA = Returns on assets, ROE = Returns on equity, NIM = Net interest margin, NPM = Net profit margin, $\mathrm{CR}=$ Credit risk, $\mathrm{CAR}=$ Capital adequacy ratio, $\mathrm{LEV}=$ Leverage, $\mathrm{INF}=$ Inflation, $\mathrm{GDP}=$ Gross domestic product, $\mathrm{OP}=$ Oil price. ${ }^{* * *}, * *$, and ${ }^{*}$ indicate $1 \%, 5 \%$ and, $10 \%$ significance level, respectively.

\subsection{Robustness Check Controlling for Oil Price Fall and the Arab Spring}

The dummy variable for Oil price fall (Dum_op) and the Arab Spring (Dum_as) were added to the model to ascertain if there will be any significant changes in the influence of the bank-specific variables and macroeconomic variables that were utilized in our study. The results as presented in Table 9 shows that the influence is the same the events show much impact on the CBs than the IBs. Both the Dum_as and Dum_op influence significantly the ROA, ROE for CBs, while only Dum_as is found to significantly influence NIM. This is an indication that the CBs banks are susceptible to crisis. However, the result reveals that Dum_as and Dum_op influence significantly the ROE, while only Dum_as impact on NPM for IBs. Moreover, the ECT coefficient from the table indicates that only Model 21 will converge back to the equilibrium in the presence of shock, and also implies that there is a stable long-run relationship between NIM and those variables that were found to be significant at the long-run for CBs. As for IBs, the ECT coefficient of Model 23 is found to be significant. This means that, in the case of disequilibrium, the model will adjust back to equilibrium at the speed rate of $73 \%$. More also, there is a presence of a stable long-run relationship between ROE and those variables that are found to be significant in the long-run for IBs.

Table 9. Long and Short-run estimates, controlling for both Arab Spring and Oil price fall.

\begin{tabular}{|c|c|c|c|c|c|c|}
\hline \multirow[b]{2}{*}{ Dep. Variable } & \multicolumn{3}{|c|}{ Conventional Banks } & \multicolumn{3}{|c|}{ Islamic Banks } \\
\hline & $\begin{array}{c}\text { ROA } \\
\text { (Model 19) }\end{array}$ & $\begin{array}{c}\text { ROE } \\
\text { (Model 20) }\end{array}$ & $\begin{array}{c}\text { NIM } \\
\text { (Model 21) }\end{array}$ & $\begin{array}{c}\text { ROA } \\
\text { (Model 22) }\end{array}$ & $\begin{array}{c}\text { ROE } \\
\text { (Model 23) }\end{array}$ & $\begin{array}{c}\text { NPM } \\
\text { (Model 24) }\end{array}$ \\
\hline \multicolumn{7}{|l|}{ Long-run coef. } \\
\hline$C R$ & $-0.018 * *$ & $-0.26^{* * *}$ & $3.18 * * *$ & 4.21 & $-0.081^{* *}$ & $-1.180 * * *$ \\
\hline$C A R$ & $0.212 * * *$ & $-2.013^{* * *}$ & $-4.41^{* *}$ & -3.09 & $-0.66^{* * *}$ & $6.105 * * *$ \\
\hline$L E V$ & $-0.0003^{* * *}$ & -0.001 & -0.004 & -0.066 & $-0.015^{* * *}$ & $0.147^{* * *}$ \\
\hline INF & $-0.001^{* * *}$ & $-0.016^{* * *}$ & $0.016 *$ & 0.148 & $-0.003^{* * *}$ & 0.016 \\
\hline$G D P$ & $-0.0008^{* * *}$ & $-0.007^{* * *}$ & $-0.045 * * *$ & -0.211 & $0.005^{* * *}$ & $0.094^{* * *}$ \\
\hline$O P$ & $0.0002 * * *$ & $0.002^{* * *}$ & -0.008 & -0.016 & 0.0002 & 0.002 \\
\hline Dum_as & $-0.001^{* * *}$ & $0.027 * * *$ & $0.263 * * *$ & -10.11 & $0.022 * * *$ & $0.314^{* * *}$ \\
\hline Dum_op & $0.0012^{* * *}$ & $0.009^{* *}$ & 0.028 & 0.293 & $0.004^{* *}$ & 0.001 \\
\hline
\end{tabular}


Table 9. Cont.

\begin{tabular}{ccccccc}
\hline & \multicolumn{3}{c}{ Conventional Banks } & \multicolumn{3}{c}{ Islamic Banks } \\
\hline Dep. Variable & $\begin{array}{c}\text { ROA } \\
\text { (Model 19) }\end{array}$ & $\begin{array}{c}\text { ROE } \\
\text { (Model 20) }\end{array}$ & $\begin{array}{c}\text { NIM } \\
\text { (Model 21) }\end{array}$ & $\begin{array}{c}\text { ROA } \\
\text { (Model 22) }\end{array}$ & $\begin{array}{c}\text { ROE } \\
\text { (Model 23) }\end{array}$ & $\begin{array}{c}\text { NPM } \\
\text { (Model 24) }\end{array}$ \\
\hline Short-run coef. & & & & & & \\
\hline$E C T$ & -0.018 & -0.015 & $-0.096^{* * *}$ & -0.002 & $-0.073^{* * *}$ & -0.045 \\
\hline$\Delta C R$ & 0.003 & 0.065 & 0.096 & 1.386 & $0.225^{* * *}$ & 40.152 \\
\hline$\Delta C A R$ & -0.16 & -0.513 & 17.34 & -4.69 & 0.583 & 5.900 \\
\hline$\Delta L E V$ & -0.003 & -0.009 & -0.089 & -0.159 & -0.009 & -0.203 \\
\hline$\Delta I N F$ & 0.0002 & 0.001 & -0.03 & -0.012 & 0.001 & 0.079 \\
\hline$\Delta G D P$ & 0.0004 & 0.0004 & 0.009 & 0.009 & 0.001 & -0.030 \\
\hline$\Delta O P$ & 0.0003 & 0.0003 & $0.004^{* *}$ & 0.0005 & 0.0002 & 0.005 \\
\hline$\Delta D$ um_as & -0.0002 & $-0.0005^{*}$ & $-0.011^{* *}$ & -0.002 & -0.0003 & $-0.0211^{* *}$ \\
\hline$\Delta D$ Dim_op & 0.0003 & 0.0007 & $-0.004 * *$ & -0.003 & -0.0008 & -0.003 \\
\hline
\end{tabular}

\section{Summary and Conclusions}

In this paper, we apply both panel ARDL techniques and the error correction model to examine whether oil price shocks and other factors will create bigger impacts on Islamic banks than conventional banks. The influences of both bank-specific and macroeconomic variables have been extensively explored in the GCC countries in the literature; however, comparison between the two types of banks: Conventional Banks (CBs) and Islamic Banks (IBs) that operate within the region have not been rigorously studied empirically. In addition, the influences of an oil price shock and the Arab Spring have not been examined empirically and exhaustively to determine which of the two types of banks is affected more. To bridge the gap in the literature, in this paper we investigate the impacts of oil price shocks, Arab revolutions, and some macroeconomics and bank-specific variables on the sustainability of bank profitability between Conventional and Islamic banks.

We use two dummy variables for the oil price shock and Arab Spring to estimate their impacts on the profitability of both CBs and IBs. In addition, we employ both bank-specific and macroeconomic variables to estimate the impacts on the profitability of both CBs and IBs. We also apply three indicators for bank profitability, three bank-specific variables (credit risk, capital adequacy, and leverage), and three macroeconomic variables (economic growth, inflation, and oil price) to estimate the impacts on the profitability of both CBs and IBs. We then apply the panel ARDL techniques and use the error correction model to examine whether there is any long or short-run causal relationship from each of the exogenous variables to each of the endogenous variables for both CBs and IBs.

Our analysis shows that oil prices significantly affect the profitability of both CBs and IBs in the GCC region. We find some conclusions drawn from our analysis are different for CBs and IBs. For example, we find that contrast to the finding when controlled Arab spring, the result when controlled for Oil price fall in respect of returning to equilibrium when disequilibrium, shows that none of the three models (ROA, ROE, and NIM) for CBs have the ability to return to equilibrium, but ROE and NPM models for IBs have the ability to return to equilibrium when there is disequilibrium, even at a low-speed rate of adjustment of $11 \%$ and $35 \%$, respectively.

There are some similar conclusions drawn from our analysis for both CBs and IBs. For example, we find that all the bank-specific and macroeconomic variables have significant and similar impacts on the sustainability of both types of banks. In addition, we find that while most of the variables employed in this study are found to influence all the three profitability indicators (ROA, ROE, NIM/NPM) significantly at the long-run for both CBs and IBs, the impact at the short-run is not significant, except OP that has generated a significant impact on ROE for CBs. The similar impacts from nearly all the variables used in our paper on all the bank's profitability indicators for both types of banks imply 
that both CBs and IBs are similar in nature, this could be because the structure of the policies for the Islamic banks is in line with the regulatory framework for the conventional banks.

It is worthy to note that while Arab spring impact negatively on ROA for CBs, it was positive for IBs in the long-run. Also significant from our finding is the ability of the models to return to equilibrium in case of shock when controlled for Arab spring. While two of the models (ROA and NIM) for CBs will return to equilibrium, only one model (ROE) has the potential of returning to equilibrium for IBs.

The findings from our empirical study that investigates the impact of oil price shocks and other factors on the profitability of both Islamic and Conventional banks from the Gulf Cooperation Council (GCC) Countries are useful to bankers and policymakers for their decision makings related to bank profitability in the GCC countries for both Islamic and Conventional Banks. For example, from our findings, bankers and policymakers could introduce or amend proper prudent macro regulations on the price of oil because the oil price is easy to monitor with the view of mitigating the unfavorable influence of oil price shocks. Besides, our study shows that change in the oil price shock could influence the profitability of both CBs and IBs in the GCC region. Thus, policymakers must recognize the homogenous influence of oil price shocks on the bank profitability of both banks.

A limitation of our paper is that we include the 20 Conventional and 20 Islamic banks from the 6 GCC countries, including UAE, Qatar, Bahrain, Kuwait, and Saudi Arabia but we have not included Oman in our study because the Islamic banking system in Oman has started later comparing to other GCC's countries and thus it does not match with data from other GCC's countries $[1,16,19,55]$. Thus, an extension of our paper is to find an approach to include Oman in the study. Another extension of our work is to including more variables that could be important in IBs and/or CBs for improving their profits. Future research could also include a comparison of our findings in the GCC countries with findings in other regions.

Author Contributions: Conceptualization, J.E.; Methodology, J.E.; software, J.E.; formal analysis, J.E.; data curation, H.R.; writing-original draft preparation W.-K.W.; writing-review and editing, W.-K.W.; supervision, H.R. All authors have read and agreed to the published version of the manuscript.

Funding: This research received no external funding.

Conflicts of Interest: The authors declare no conflict of interest.

\section{References}

1. Siraj, K.K.; Pillai, P.S. Comparative study on performance of Islamic banks and conventional banks in GCC region. J. Appl. Financ. Bank. 2012, 2, 123.

2. Johnes, J.; Izzeldin, M.; Pappas, V. A comparison of performance of Islamic and conventional banks 2004-2009. J. Econ. Behav. Organ. 2014, 103, 93-107. [CrossRef]

3. Jan, A.; Marimuthu, M. Sustainability profile of islamic banking industry: Evidence from world top five islamic banking countries. Int. J. Econ. Financ. 2015, 7, 125-139. [CrossRef]

4. Abduh, M.; Idrees, Y. Determinants of Islamic banking profitability in Malaysia. Aust. J. Basic Appl. Sci. 2013, 7, 204-210.

5. Alkassim, F.A. The profitability of Islamic and conventional banking in the GCC countries: A comparative study. J. Rev. Islamic Econ. 2005, 13, 5-30.

6. Bashir, A.H. Determinants of Profitability in Islamic Banks: Some Evidence from the Middle East. Islamic Econ. Stud. 2003, 11, 31-57.

7. Srairi, S.A. Factors influencing the profitability of conventional and Islamiccommercial banks in GCC countries. Rev. Islamic Econ. 2009, 13, 5-30.

8. Wasiuzzaman, S.; Tarmizi, H.A.B.A. Profitability of Islamic banks in Malaysia: An empirical analysis. J. Islamic Econ. Bank. Financ. 2010, 6, 53-68.

9. Kalifa, W.; Bektaş, E. The impacts of bank-specific and macroeconomic variables on the capital adequacy ratio: Evidence from Islamic banks. Appl. Econ. Lett. 2018, 25, 477-481. [CrossRef]

10. Hassoune, A. Islamic Banks Profitability in an Interest Rate Cycle. Int. J. Islamic Financ. Serv. 2002, 4, 1-13. 
11. Jaffar, M.; Manarvi, I. Performance comparison of Islamic and Conventional banks in Pakistan. Glob. J. Manag. Bus. Res. 2011, 11, 1-7.

12. Asutay, M.; Izhar, H. Estimating the profitability of Islamic banking: Evidence from bank Muamalat Indonesia. Rev. Islamic Econ. 2007, 11, 17-29.

13. Haron, S. Determinants of Islamic bank profitability. Glob. J. Financ. Econ. 2004, 1, 11-33.

14. Rjoub, H.; Civcir, I.; Resatoglu, N.G. Micro and macroeconomic determinants of stock prices: The case of Turkish banking sector. Rom. J. Econ. Forecast. 2017, 20, 150-166.

15. Olson, D.; Zoubi, T.A. Using accounting ratios to distinguish between Islamic and conventional banks in the GCC region. Int. J. Account. 2008, 43, 45-65. [CrossRef]

16. Loghod, H.A. Do islamic banks perform better than conventional banks? Evidence from gulf cooperation council countries. J. Manag. 2010, 7, 56-72.

17. Hutapea, E.G.; Kasri, R.A. Bank margin determination: A comparison between Islamic and conventional banks in Indonesia. Int. J. Islamic Middle East. Financ. Manag. 2010, 3, 65-82. [CrossRef]

18. Rjoub, H.; Tursoy, T.; Gunsel, N. The Effects of Macroeconomic Factors on Stock Returns: Istanbul Stock Market. Stud. Econ. Financ. 2009, 26, 36-45. [CrossRef]

19. Hasan, M.; Dridi, J. The effects of the global crisis on Islamic and conventional banks: A comparative study. J. Int. Commer. Econ. Policy 2011, 2, 163-200. [CrossRef]

20. Yoshizaki, Y.; Hamori, S. On the influence of oil price shocks on economic activity, inflation, and exchange rates. Int. J. Financ. Res. 2013, 4, 33. [CrossRef]

21. Berument, M.H.; Ceylan, N.B.; Dogan, N. The impact of oil price shocks on the economic growth of selected MENA countries. Energy J. 2010, 31, 149-176.

22. Gazdar, K.; Hassan, M.K.; Safa, M.F.; Grassa, R. Oil price volatility, Islamic financial development and economic growth in Gulf Cooperation Council (GCC) countries. Borsa Istanb. Rev. 2019, 19, 197-206. [CrossRef]

23. Alfadli, A.; Rjoub, H. The impacts of bank-specific, industry-specific and macroeconomic variables on commercial bank financial performance: Evidence from the Gulf cooperation council countries. Appl. Econ. Lett. 2019. [CrossRef]

24. Al-Khazali, O.M.; Mirzaei, A. The impact of oil price movements on bank non-performing loans: Global evidence from oil-exporting countries. Emerg. Mark. Rev. 2017, 31, 193-208. [CrossRef]

25. Lee, C.C.; Lee, C.C. Oil price shocks and Chinese banking performance: Do country risks matter? Energy Econ. 2019, 77, 46-53. [CrossRef]

26. Abeysinghe, T.; Rajaguru, G. Quarterly real GDP estimates for China and ASEAN4 with a forecast evaluation. J. Forecast. 2004, 23, 431-447. [CrossRef]

27. Chow, G.C.; Lin, A. Best linear unbiased interpolation, distribution, and extrapolation of time series by related Series. Rev. Econ. Stat. 1971, 53, 372-375. [CrossRef]

28. Pesaran, M.H.; Shin, Y.; Smith, R.J. Pooled mean group estimation of dynamic heterogeneous panels. J. Am. Stat. Assoc. 1999, 94, 621-634. [CrossRef]

29. Levin, A.; Lin, C.; Chu, C. Unit root tests in panel data: Asymptotic and finite-sample properties. J. Econom. 2002, 108, 1-24. [CrossRef]

30. Im, K.; Pesaran, H.; Shin, Y. Testing for unit roots in heterogeneous panels. J. Econom. 2003, 115, 53-74. [CrossRef]

31. Westerlund, J. Panel cointegration tests of the Fisher effect. J. Appl. Econom. 2008, 23, 193-233. [CrossRef]

32. Odugbesan, J.A.; Rjoub, H. Relationship among HIV/AIDS Prevalence, Human Capital, Good Governance, and Sustainable Development: Empirical Evidence from Sub-Saharan Africa. Sustainability 2019, 11, 1348. [CrossRef]

33. Pesaran, M.H.; Schuermann, T.; Weiner, S.M. Modeling regional interdependencies using a global error-correcting macroeconometric model. J. Bus. Econ. Stat. 2004, 22, 129-162. [CrossRef]

34. Rjoub, H. Stock prices and exchange rates dynamics: Evidence from emerging markets. Afr. J. Bus. Manag. 2012, 6, 4728-4733.

35. Ali, M.; Puah, C.H. Does bank size and funding risk effect banks' stability? A lesson from Pakistan. Glob. Bus. Rev. 2018, 19, 1166-1186. [CrossRef]

36. Djalilov, K.; Piesse, J. Determinants of bank profitability in transition countries: What matters most? Res. Int. Bus. Financ. 2016, 38, 69-82. [CrossRef] 
37. Almaqtari, F.A.; Al-Homaidi, E.A.; Tabash, M.I.; Farhan, N.H. The determinants of profitability of Indian commercial banks: A panel data approach. Int. J. Financ. Econ. 2019, 24, 168-185. [CrossRef]

38. Jara-Bertin, M.; Arias Moya, J.; Rodriguez Perales, A. Determinants of bank performance: Evidence for Latin America. Acad. Rev. Latinoam. De Adm. 2014, 27, 164-182. [CrossRef]

39. Yahya, A.T.; Akhtar, A.; Tabash, M.I. The impact of political instability, macroeconomic and bank-specific factors on the profitability of Islamic banks: Anempirical evidence. Invest. Manag. Financ. Innov. 2017, 14, 30-39. [CrossRef]

40. Ariyadasa, C.; Selvanathan, E.A.; Siddique, M.A.B.; Selvanathan, S. On the profitability of commercial banks: The Sri Lankan case. Appl. Econ. 2017, 49, 2106-2116. [CrossRef]

41. Fiordelisi, F.; Marques-Ibanez, D.; Molyneux, P. Efficiency and risk in European banking. J. Bank. Financ. 2011, 35, 1315-1326. [CrossRef]

42. Chowdhury, M.A.F.; Haque, M.M.; Masih, M. Reexamining the determinants of Islamic bank performance: New evidence from dynamic GMM, quantile regression, and wavelet coherence approaches. Emerg. Mark. Financ. Trade 2017, 53, 1519-1534. [CrossRef]

43. Karim, M.A.; Hassan, M.K.; Hassan, T.; Mohamad, S. Capital adequacy and lending and deposit behaviors of conventional and Islamic banks. Pac.-Basin Financ. J. 2014, 28, 58-75. [CrossRef]

44. Bitar, M.; Madiès, P.; Taramasco, O. What makes Islamic banks different? A multivariate approach. Econ. Syst. 2017, 41, 215-235. [CrossRef]

45. Bucevska, V.; Hadzi Misheva, B. The determinants of profitability in the Banking industry: Empirical research on selected Balkan countries. East. Eur. Econ. 2017, 55, 146-167. [CrossRef]

46. Adusei, M. The impact of bank size and funding risk on bank stability. Cogent Econ. Financ. 2015, 3, 1-19. [CrossRef]

47. Ongore, V.O.; Kusa, G.B. Determinants of financial performance of commercial banks in Kenya. Int. J. Econ. Financ. Issues 2013, 3, 237-252.

48. Tan, Y.; Floros, C. Bank profitability and GDP growth in China: A note. J. Chin. Econ. Bus. Stud. 2012, 10, 267-273. [CrossRef]

49. Rashid, A.; Jabeen, S. Analyzing performance determinants: Conventional versus Islamic banks in Pakistan. Borsa Istanb. Rev. 2016, 16, 92-107. [CrossRef]

50. Garcia, M.T.M.; Guerreiro, J.P.S.M. Internal and external determinants of banks' profitability the Portuguese case. J. Econ. Stud. 2016, 43, 90-107. [CrossRef]

51. Yanikkaya, H.; Gumus, N.; Pabuccu, Y.U. How profitability differs between conventional and Islamic banks: A dynamic panel data approach. Pac.-Basin Financ. J. 2018, 48, 99-111. [CrossRef]

52. Sigmund, M.; Gunter, U.; Krenn, G. How Do Macroeconomic and Bank-specific Variables Influence Profitability in the Austrian Banking Sector? Evidence from a Panel Vector Autoregression Analysis. Econ. Notes 2017, 46, 555-586. [CrossRef]

53. Sun, P.H.; Mohamad, S.; Ariff, M. Determinants driving bank performance: Acomparison of two types of banks in the OIC. Pac.-Basin Financ. J. 2017, 42, 193-203. [CrossRef]

54. Knezevic, A.; Dobromirov, D. The determinants of Serbian banking industry profitability. Econ. Res.-Ekon. Istraživanja 2016, 29, 459-474. [CrossRef]

55. Khediri, K.B.; Charfeddine, L.; Youssef, S.B. Islamic versus conventional banks in the GCC countries: A comparative study using classification techniques. Res. Int. Bus. Financ. 2015, 33, 75-98. [CrossRef]

(C) 2020 by the authors. Licensee MDPI, Basel, Switzerland. This article is an open access article distributed under the terms and conditions of the Creative Commons Attribution (CC BY) license (http://creativecommons.org/licenses/by/4.0/). 